\title{
Ethno-Nationalism and Identity Conflicts in Nigerian History: The Niger Delta Situation to 2012
}

\author{
Atei Mark Okorobia, PhD \\ Department of History \& Diplomatic Studies, Faculty of Humanities, \\ University of Port Harcourt, Nigeria \\ Stephen Temegha Olali \\ Department of History \& Diplomacy, Faculty of Arts, \\ Niger Delta University, Wilberforce Island, Bayelsa State, Nigeria
}

Doi:10.5901/mjss.2013.v4n4p431

\begin{abstract}
While the Niger Delta remains one of the most studied regions of Nigeria, its contributions to the history of ethno-nationalism and identity conflicts have not been adequately documented. This paper explores the roots, manifestations and consequences of ethno-nationalism and identity conflicts in Nigeria, with emphasis on the Niger Delta region since pre-colonial times.
\end{abstract}

\section{Introduction}

Generally, nationalism is a feeling of community among a people based on common history, descent, language, ideology and religion. Before the 20th century when nationalism emerged as a distinctive movement in Nigeria, the states were usually based on religious or dynastic ties and citizens owed loyalty to their ethnic groups, clans, villages or ruling families. With such focus, the people rarely extended their interests to wider national concerns. Historically, then, the tendency toward nationalism was fostered by various technological, cultural, political, and economic advances. Improvement in communications extended the knowledge of people beyond the confines of their community. The spread of education in native tongues among the masses provided extra vent for their participation in a common cultural heritage. They learned more of their common history and culture, and began to identify themselves with the historical continuity of the nation. The introduction of national constitutions and the struggle for political rights gave peoples the sense of helping to determine their fate as a nation and of sharing responsibility for the future well-being of that nation. The growth of trade and industry also laid further foundation for economic units larger than the traditional geo-political expressions (Kohn, 2009:1).

In the context of Niger Delta history, ethno-nationalism and identity conlicts are closely associated with two other factors, namely, the history of state formation in different parts of the region; the role different groups or communities played during the Atlantic trade; and their respective positions under the British colonial administrative system. This study investigates the roots, manifestations and consequences of ethno-nationalistic sentiments and identity conlicts in the Niger Delta region of Nigeria since pre-colonial times. We have in the course of exploring this broad goal, sought to interrogate the interactional processes and intergroup relations within the Niger Delta, highlighting the patterns of cooperation and conflict in relationship to each other, and between the latter and other ethnic nationalities in Nigeria, especially their super-ordinate neighbours.

For our present purpose, we have defined the Niger Delta spatially, to include only the core areas that are coterminous with the three states of Bayelsa, Delta and Rivers in South-South Nigeria. This was where the European supercargoes did the greater part of their business in the heyday of the Atlantic Trade in slaves and oil-palm produce prior to the birth of Nigeria. It is also where the bulk of the Nigeria's current hydro-carbon resources are exploited, and yet, had remained the least developed.The human and historical geography of the area indicate that among the Niger Delta peoples are the ljo, Ogoni, Urhobo, Itsekiri, Ukwuani (Ndokwa), Epie/Atissa, Ogbia, Abua, Odual (Saka), Abureni (Mini), Ikwerre, Etche,Ekpeye, Ogbah, Egbema, etc. From her linguistic study of Niger Delta, Williamson (1988: 95) draws significant inferences that are relevant to a picture of inter-group relations and migrations in prehistoric times. In sum, it is inferred that the ancestors of the ljo (composed of the Izon, Nembe, Akassa, Kalabari, Bile, Okrika, Ibani, Nkoro,etc) have 
been in the region for about 7,000 years. However, the ancestors of the Central Delta (composed of Ogbia, Abua, Odual (Saka), Abureni (Mini),Bukuma, Abuloma) arrived about 2,000 years ago from an easterly direction to displace the original ljo speakers. Shortly after this, (but also before 2,000 years ago) the proto-Delta Edoid group (made up of Epie/Atissa, Engenni, Degema) came from a westerly direction into the Niger Delta living contiguously to the ancestors of the South-Western Edoid (Urhobo and Isoko). A southward movement of Igboid speakers (Ukwuani, Ikwerre, Etche, Ekpeye, Ogbah, Egbema, etc) and an opposite movement of the ljo, separated the Delta Edoid from the South-West Edoid group at about the same period of 2,000 years ago.

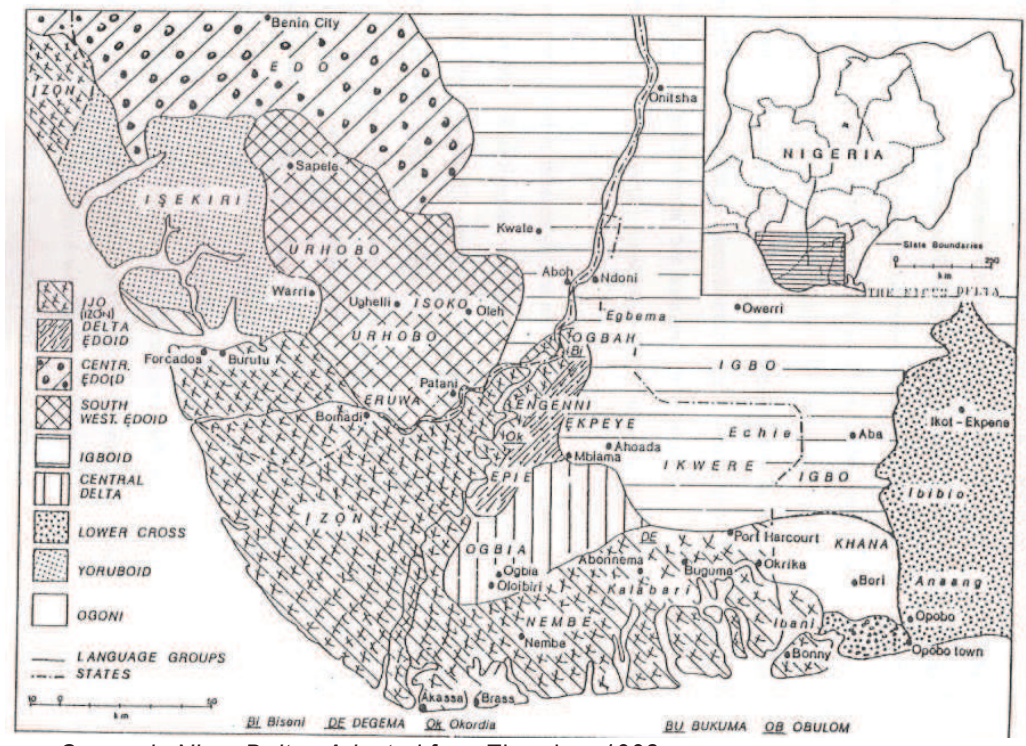

Fig. 1: Language Groups in Niger Delta. Adapted from Eboreime,1992.

\section{Ethno-Nationalism and Identity Conflicts in Nigeria: An Overview}

The British inspired evolution of the Nigerian state is structurally defective, and has accordingly, shown several political imbalances between and within the disparate ethnic nationalities. One area where this is most apparent is in the international and regional boundaries that have been drawn up in such a manner that many minority groups within the three ethnic majors, the Hausa/Fulani in the North, Yoruba in the South-West and lgbo in the South-East have been encapsulated, and their cultural identities largely suffocated (Coleman 1960). This structure was given legal backing by colonial constitutions which guaranteed to the Northern Region a size and population that assured her dominance of the other two regions put together. This laid the foundation for the political and ethnic conflicts between the ethnic majorities on the one hand, and between them and the minorities on the other (Eboreime,1992). In the heyday of regionalism, it was common for people to assume that every Northern Nigerian was an 'Hausa' man, evry Easterner an 'Igbo', and that those in the Western Region were 'Yoruba'. The minorities' ethnic identities and developmental aspirations were general ignored or compromised. While the struggles between the ethnic majors were focused on the distribution of power and its perquisites, minority agitations were motivated by the need to protect and preserve their ethnic identities, and to secure developmental attention.

As Nigeria sorjourned towards political independence, the fears of the minorities became even more intense. Under colonialism, the Niger Delta was not only fragmented between the Western and Eastern Regions but its scores of ethnic minorities were also encapsulated by their majority neighbours, especially the Yoruba of the West and the Igbo of the East. In their struggle for ethnic identity and political autonomy to attract greater developmental attention, the Niger Delta ethnic nationalities tabled their case in the series of Constitutional Conferences in London between 1957 and 1958. Though the minorities saw the creation of states as the solution to their marginalization, this option was neither favoured by the ethnic majorities nor the British authorities. Their reason was that it would compromise the more popular demand for an early political independence for the country. In appreciation of the peculiar developmental challenges of the Niger 
Delta, however, a 'special area' status was granted to the region, which was then defined as "...three Divisions (Ogoni, Degema and Brass) together with the Western ljaws" (Willink, 1958:51). In effect, this essentially means the ljo (ljaw) and Ogoni lands constituted the British recognised Niger Delta 'Special Area'. Arising from this a Niger Delta Development Board, the first of a series of efforts aimed at giving attention to the developmental problems of the region was created. That Board, like its successors, achieved little as it was starved of the needed fund to execute its proposals. It was obvious that the soul of the Nigerian nation has had little place for the peoples of the Niger Delta (Ikimi, 2006).

As Eboreime (1992) aptly observes, the Nigerian civil war (1967-70), as well as the incessant agitation for new states, local governments and wards are symptomatic of the persistence of structural imbalance, minority problems and ethnic conflicts. The 1966 military intervention in Nigerian politics at a time when petroleum was becoming the most important single foreign exchange earner added a new dimension to Nigeria's political economy and the national question (Panter-Brick 1978). Competitive politics, in the absence of political parties, started manifesting itself in the agitation for more and more states even within ethnically homogeneous states. From three regions under the British in 1914 and four in 1963, subsequent military administrations dominated by the ethnic majorities, started creating more states and local government units, many without legitimate justifications, except as a means of attracting more oil revenue to their sections of the country. From 12 states in 1967; 19 in 1976; 30 in 1991; Nigeria now has 36 states and 774 Local Government Areas since 1996.

As the Niger Delta ethnic minorities remained encapsulated within their majority neighbours outside the delta, there was another interesting development within. The less influential or micro-minorities within the region were also complaining against the more influential or mega-minorities such as the ljo and Itsekiri. Sometimes, these protest took traditional dimension where demands were for new chieftaincy stools by interest groups which felt shortchanged. At other times it took violent dimension. It is against these multi-polar tendencies of centralization as exemplified by colonial/military rule at upper levels, and decentralization as epitomized by fragmentation at more inclusive lower levels, that this study of new "micro-minorities" activated at levels, lower than the major minorities themselves, becomes relevant to the understanding of a political system that is evidently in a state of flux (Eboreime, 1992:2).

An evidence for the rise in the incidence of ethno-nationalism and identity conflicts in Nigeria is that while 395 ethno-linguistic groups were recorded by Bendor-Samuel in 1982, the number had risen to 440 by 1992 (Eboreime 1992). This confirms the tendency in Nigeria for linguistic groups to activate their latent identities and behave as ethnic groups in favourable circumstances. This has been aided by two factors. First, the withdrawal of the colonial regime under which majority languages were promoted to the disadvantage of the minor ones has led to a massive reaction in independence times on the part of these minorities in deliberately asserting their identities through the promotion of their languages and culture. Secondly, the adoption of the quota system, the creation of states and other local units of administration have also encouraged the activation of latent identities through resort to linguistic and cultural differences.

\section{Ethno-Nationalism and Identity Conflicts in Niger Delta}

National consciousness among Nigerians is an evolving phenomenon. However, as we alluded to earlier, in the context of Niger Delta experience, ethno-nationalism and identity conlicts are closely associated with three specific factors. For some groups, the first factor is the growth of trade and industry. The second, third and fourth factors more general in nature. They include their history of state formation, the role played by the different groups, communities and ethnic nationalities during the Atlantic trade; as well as their respective roles and positions under the British colonial administrative system.For emphasis we may discuss some these.

\subsection{State Formation}

According to Alagoa ( 1970 and 1971), the Niger Delta region has been occupied by humans for over ten thousand years, and by the time the Europeans first arrived in the fifteenth century. A number of centralized politities had risen, especially in places like Itsekiriland, and among the eastern ljo groups of Nembe, Kalabari, Okrika and Ibani. It was with these centralized states, (also known as the city states or trading states) that the early European supercargoes traded. The Europeans did not establish these states. Their foundation is traceable to an earlier internal long distant trade across the length and breadth of the delta, and between them and their mainland neighbours. The Itsekiri kingdom was one of these centralized polities which rose due to their effective response to the challenges of trans-delta and delta-hinterland trade (Ikimi 2006). We note at this point, that whereas the Itsekiri and the ljo of the Eastern Delta developed city-states, their Western Delta sibblings in today's Delta and Ondo States, did not, probably because of the rise of the Itsekiri kingdom and its control of the trade of the Escravos and Forcados rivers. The ljo of the Western Delta were only identified as 
'pirates'. Indeed, following the publication of Dike (1956) which dealt with the city-states of the Eastern Delta, the term, "Niger Delta" came to be used as if the Eastern Delta was what constituted the entire Niger Delta! Ikimi (1968 and 1969) were written to correct this impression. The point to stress here is that although a people may exist in their habitat for thousands of years, until such a people emerge on the pages of history, it is as if they do not exist. What is true of the Western ljo is also true of the Ukwuani or Ndokwa in the same area. As this study espouses, this has had enormous implications for ethno-nationalism and identity conflicts in the Niger Delta. In their competition for access to the benefits of the Atlantic trade in slaves and oil-palm produce, some states were better placed to tap the trade than others. This bred inter-state hostilities, and sometimes, wars. Between 1863 and 1871, for example, Bonny fought Kalabari; Bonny and Okrika fought against Kalabari and, Kalabari fought Nembe (Wariboko 1989:128). Bille and Nembe also clashed at about this period over an earlier attack on Nembe merchant boat by Bille pirates. And so, even though these states had a common culture and shared identical environment, European accounts from the 15th century identified some groups as 'pirates'. In the eastern delta, inter-group hostilities and/or wars sometimes arose also from conflicting claims to land and fishing grounds. Interestingly, tradtions from the homes of the 'pirates' identify them as local 'heroes', and 'patriots'. These conflicting identities are understandble. Having been denied access to the benefits of the Atlantic trade, these acephalous societies had little or no option than preying on the trade of other states which had a larger slice of the trade. Were the situation reversed, the Itsekiri would most probably have done the same (Ikimi 2006). The degree of national consciousness among the disparate ethnic groups would however be accellerated under British rule.

\subsection{British Colonialism}

While it is obvious from the preceding section that the degree of national consciousness among the disparate ethnic groups was minimal in most communities in pre-colonial Niger Delta, a number of policies and programmes contributed in accellerating ethno-nationalism and identity conlicts under British rule and beyond. Using the cases of the Urhobo and and their neighbours in the Western Delta, the Epie-Atissa and their neighbours in the Central Delta, and the Nembe and their neighbours in the Eastern Delta, we will explore this issue and its consequences for inter-group relations in the region.

\subsection{The Western Delta: The Itsekiri, Urhobo and Isoko}

While to an extent we may say that ethno-national consciousness was for various historical reasons more developed among the Itsekiri than their Urhobo and Isoko neighbours in pre-colonial times, the consolidation of British rule facilitated ethnic nationalism and identity conflict in the Western Delta. Before colonial rule, except in the case of war, the people generally decided their own fortunes. Thus, purely on the basis their need they decided to enter into whatever relationships they desired, including alliance for peace and war with one another at various settings. The British presence changed much of this. They, for example, imposed on these groups administrative arrangements and identities without the slightest courtesy of consulting them. The people were at different times grouped together and labelled as 'Western Division', 'Central Province', 'Warri Province', 'Jekri-Sobo Division' and so on. Over time these names came to have great emotive power. It was precisely because of this emotive power that the name 'Warri Province' was changed to 'Delta Province'. These administrative arrangements invariably favoured some groups and put others at a disadvantage. From 1900 onwards when the British began to set up native courts in these parts, for example, these courts were not set up in every village or clan, and only members appointed by the British could sit on those courts. Centres where these courts held became relatively more important than others, while Court members also acquired a new importance in society. Whether or not these results were intended, colonial rule began to introduce into the society new inequalities and new tensions which erupted into violence as it happened in Warri in 1952. The British, wittingly or unwittingly, subjected certain groups to others in trying to set up a Native Court of Appeal to which all the ethnic groups in the Province had to send their appeals. When an Isoko, ljo or Urhobo case came up to the Native Court of Appeal in Warri, presided over by Omadoghogbone Numa, an Itsekiri, which native law and custom was to be administered? Did all the ethnic groups have judges sitting on the Court of Appeal? No. There was thus a great deal of discontent. The British decided to reorganize the Native Administration so that each ethnic group would have its own institutions. They created the Jekri-Sobo Division which had in it the Itsekiri and a number of Urhobo groups on the ground that the Itsekiri and these Urhobo groups were so inter-mixed that they would fuse into one in the future. But the Urhobo in this Division continued to protest their continued subjection to the Itsekiri who were seen as British allies in the violation of the Urhobo territorial integrity. The Itsekiri also acted as british guides and interpreters, as well as the first native courts judges and clerks in Urhoboland inspite of the objections by the Urhobo. The Urhobo also argued that they paid more tax to the coffers of the Division than 
did the Itsekiri and that their tax money was being used to develop the Itsekiriland. Eventually, the British had to yield to the protest. The Urhobo were excised from the Jekri-Sobo division and a Western Sobo Division was created for them with headquarters at Ughelli. The importance which Ughelli came to acquire in Urhoboland is owed to this decision. It was the first place in Urhoboland where a British colonial official resided. The Sobo Division, however, included the Isoko who are not Urhobo. Other Divisions created were the Western ljo Division and the Kwale Division.

The tensions which the Jekri-Sobo Division threw up lingered on even after the Western Sobo Division had been created and were fuelled by the Sapele land case in which the Olu sought to claim Sapele land as Itsekiriland on the grounds that the deed which gave parts of Sapele to the British was signed by Chief Dogho Numa, an Itsekiri who, the Olu argued, acted on behalf of the Itsekiri ruler. The case went as far as the West African Court of Appeal where the Olu lost it. Of course the British eventually tried to respond favourably to the Urhobo petitions. The Itsekiri who saw themselves as British allies viewed this as a betrayal. In their reaction, however, they turned their anger against the Urhobo rather than the British. In the long run then, the Urhobo continued to be victims in this colonial administrative misadventure (Ikimi, 2006). Clearly, ethno-nationalism and identity conflicts had been accentuated by the British colonial administrative arrangements.

\section{The challenge of Isoko Identity and Ethno-Nationalism}

Though related to the Urhobo, the Isoko constitute an ethnic nationality of their own- a micro-minority, and so, just as the Urhobo in the Jekri-Sobo Division protested their inclusion in that Division, so did the Isoko protest their being in the Sobo Division. Unfortunately for the Isoko, no one listened to their protests until two years after Nigeria's independence when the Isoko got a separate Division. Even then, the official representative of the Isoko in the Western House of Assembly was designated as the "member for Urhobo East"! This was an apparent denial of his true ethnic identity. For a long time, this administrative arrangement became an excuse for the Urhobo to claim that the Isoko were Urhobo, even though there is no historical evidence to substantiate this claim, except that the British administrative arrangements put the headquarters of the division to which Isokoland belonged in Ughelli, an Urhobo community. This unfortunate arrangement forced the Isoko to go to Ughelli to attend court (at a certain level and to learn to speak Urhobo language. Some Isoko parents also had to give their daughters in marriage to Ughelli men in order to access lodging places when they had to go to Ughelli for many official purposes. Ironically, the Urhobo were opposed to the efforts of the Isoko to get a division of their own, and therefore, denying the Isoko their nationalist identity.

In the Western Delta, it is obvious that the challenges of ethno-nationalism and identity conflict would not have been greeted with so much animosity if not for the the equally provocative role played by the local politicians. In 1952, for instance, the Action Group-controlled government of the Western Region changed the title of the ruler of the Itsekiri people from 'Olu of Itsekiri' to 'Olu of Warri' against the protest and claims of the other stake-holders in the Warri area. Indeed, it was on account of this change, that the name, Warri Province was also changed to Delta Province, along with the names of several other institutions such as the Warri College, Ughelli, which was renamed Government College, Ughelli. The issue here is that if being a'Warri'person' is now synonymous with being an Itsekiri, it had become unwise for an ljo, Urhobo or Isoko to share in that identity, as they are not under the jurisdiction of the Itsekiri traditional stool, now relabelled as the 'Olu of Warri'. On the whole, then, we can agree no less with Ikimi (2006) that:

'...in the matter of inter-group relations, we are not dealing with saints and villains; we are dealing with villains all. Whichever groups are favoured by a particular administrative arrangement want to hold on to it and to exploit it as much as possible to their maximum advantage. It is human nature. Yet what is good for the goose is good for the gander'.

\section{Central Delta: The Challenges of Epie-Atissa versus Izon Ethno-Nationalisms}

Eboreime (1992) stands out as a classic among the extant studies on the Epie-Atissa, a Delta-Edoid micro-ethnic nationality in the Central Niger Delta. This group is an example per exellence of ethno-nationalism and identity conflicts in the region. According (Eboreime, 1992:...), at every phase in Epie-Atissa history, there has been a relationship and internal dynamic between imposed and local factors at play. These have created varying patterns of identity and alliance in accordance with collective group or class interests. In the pre-colonial era, demographic factors, marriage patterns and alliances responded to economic factors, leading to two broad ecological and occupational zones- the Epie (land wards) and the Atissa (water wards). It is on account of their cultural and linguistic affinities, which form the basis of their 
solidarity, that their heterogeneous features are explained in terms of language shift, rather than as an Edo conquest as Sorgwe (1990) had postulated.

The superimposition of colonial administrative units and the associated paraphernalia of the court, school and church in the hands of the ljo(Izon) majority awakened and redirected their latent identities into political use. On this, the year 1927 was a watershed. This was when the Epie and Atissa jointly petitioned against their inclusion in the ljo Council Area, and was therefore, the zenith of a united Epie-Atissa solidarity and ethno-nationalist struggle against the apparent and percieved ljo (Izon) hegemony. The dawn of this Epie-Atissa solidarity was given added impetus by the existing linguistic affinity and geographic contiguity between both moities. This nationalist sentiment was however shortlived. Conflict arose from the struggles for the perquisites of local power by the different interest groups in the colonial period. Class and community identities therefore began to assume broad Epie versus Atissa identities.

At the height of Nigerian nationalist agitations in the 1950s indigenous political parties were formed with people of Niger Delta extraction in their membership. However, because the dominant positions in these political groups were for the most, berthed in the hands of the ethnic majors, the minorities also had to design alternative platforms to exert extra pressures on the leaders both at the regional and national scenes. One major concern of the ljo was the creation a separate Oil Rivers State to free the Niger Delta from the larger and more inluential Igbo of South-Eastern Nigeria. Locally, the different micro-ethnic nationalities reacted to this atmosphere in different ways. In Epie-Atissaland interests oscillated among the Epie and Atissa between fissiparous local issues and centripetal wider issues. They were, for instance, in agreement over the status of Yenagoa as a district headquaters, but at odds over the issue of the traditional headship of the clan. Again, cetrifugal forces took a better part of them when the issue of women's "riots" or protest in the Eastern Region against the failed NCNC election promise to abolish school fees came up. In Epie-Atissa, the protest took a local dimension in terms of perceived Atissa domination and Epie subordination. The same pattern of relationships is replicated in the survival-coping phase when the Nigerian civil war (1967-68) sharpened an increased sense of a joint Epie-Atissa solidarity in the face of hostile ljo neighbours who saw them as saboteurs for benefiting from the war-time trade which their strategic location had fortuitously put them.

The post-war epoch with its peculiar pattern of civilian-military take-overs and associated reforms has seen an increased education, youths' and women's consciousness being generated in various organisations and interest groups, who forged alliances with new breed against old brigade politicians as pressure groups in the absence of political parties and sustained local government system. The 'new breed' versus 'old brigade' politics is exemplified in the rivalry between the Epie and Atissa clan heads on the one hand, and the strong intervention by the pan-Epie-Atissa educated elite movement championed by the post-war Epie-Atissa Students Union dramatically transformed the political configurations in favour of a united and inclusive Epie-Atissa interests.

Again, in their ability to optimise their valuable criss-crossing ties, networks, historical and personal links, overlapping boundaries, alliances and external relations within the context of Northern versus Southern ljo rivalry, the Epie-Atissa have, irrespective of their size, jointly begun to enjoy enormous patronage and benefits from the Local, State and Federal Governments. Since the 1990s, they have also thawed tensions that would have resulted into open warfare within them on the one hand, and between them and their near and distant neighbours on the other hand. By 1990, for example, the first elected Chairman of the Yenagoa Local Government was an Atissa youth; while in 1991, the Attorney General and Commissioner for Justice of the old Rivers State was a barrister of Epie-Atissa extraction. Again, in 1996 when the issue of states and local government creation became central and topical, inspite of the equally formidable support received by contending ljo towns like Kaiama, Amassoma/Wilberforce Island, and Ogbia Town, Yenagoa won as the capital of Bayelsa State, created from Rivers State. We notice that the employment of similar strategy in the past had resulted in the actualization of the Yenagoa-Mbiama road, while other issues such as the demand for new electoral wards and first class chieftaincy stools made for division between the duo.

This has produced an ever present toeing and froing pattern of bifocal political relationship between the Epie and Atissa in which various interest groups handled the baton of joint Epie-Atissa unity at various times and occasions. At one time it was the traditional elites; at another it was the women in the shape of new religious movements, and yet at others, it was the youths of both communities flying the solidarity flag of a joint community (Eboreime 1992).

On the whole, Eboreime (1992) has more than anyone else, aided our attempt at examining the place and use of history in defining interests, alliances and identities within the Epie-Atissa context. We see new identities as cultural and political products of contrasting historical processes (Eboreime, 1992:2). Within a century we could notice the growing sense of a corporate Epie-Atissa nationhood from pre-colonial times when it was apparently nonexistent up to the early colonial phase when it gradually developed, through the main colonial phase when it bifurcated along competing elite interest lines, to the contemporary time when it has assumed a dual structure of two feuding moieties; cooperating and competing in various spheres in a regulated, institutionally channeled way. These have been treated within the immediate 
context of an equally growing but relatively wider ljo nationalism which in itself was a response to a perceivably fierce Igbo awareness that had emerged out of an imposed colonial tripartite regional ethnic polity called Nigeria.

\section{The Eastern Delta: The Challenges of Identity Crises and Micro-Nationalism in Nembeland}

No discussion of the history of ethno-nationalism and identity conlicts in Nembeland would convey much meaning without a prior clarification of the concept, 'Nembe', and a discussion of the evolution of the ethnic nationality, both of which have become very controversal, lately. Nembe (also referred to as Brass or Nembe-Brass), is one of the major Niger Delta city-states. The name "Nembe" means more than one thing. As the Nembe-Se, it refers to the Nembe microethno-nationality, a sub-group of the larger ljo ethnic nationality. As Nembe-bibi, it is the name of the ljo dialect spoken in the Eastern part of Bayelsa State. Again, as a settlement, Nembe is the collective name of the two principal moieties of the Nembe metropolis, namely the Bassambiri and Ogbolomabiri communities with their affiliated micro-islands. In other words, Bassambiri and Ogbolomabiri together with some four other smaller settlements traditionally attached to them (Oruamabiri and Okipiri to Bassambiri; and Igopiri and Tubopiri to Ogbolomabiri) are referred to as the 'Nembe Town' or 'Nembe City'. A small creek separates the Bassambiri/Oruamabiri part of the city from the Ogbolomabiri part, while Okipiri, Igopiri and Tubopiri are on separate islands. Together, however, they serve as the headquarters of the Nembe Local Government Area and the council (Crowther, 1907:88). Over the millennia, the erstwhile autonomous and semiautonomous Mini and Okoroma group of communities have increasingly become important members and stakeholders of the Nembe nation. As the Nembe-Se grew, many of the Ikensi, Oluasiri, Obioku and Igbeta-Ewoama group of communities were also established by migrant farmers, fisherfolks, merchants and warlords from the older settlements. The other major communities in Nembe-Se are the Kingdoms of Okpoama, Twon-Brass and Odioama, as well as the Cape Formosa group of communities, all of which are presently in the Brass Local Government Area of Bayelsa State. They were all established by bands of independent ljo adventurers from dispersal points in the Central Niger Delta, particularly Obiama, now extinct. For various reasons, prominent among which is the domineering and exploitative attitude of the Nembe metropolitan communities (Ogbolomabiri and Bassambiri), the Akassa, have in recent times dissociated themselves from been identified as part of the Nembe nation, and are therefore excluded. At the height of their imperial power and glory, however, the Nembe exerted their influence over virtually the entire Bayelsa (excluding perhaps, the Ekeremor and Sagbama areas), and the western parts of Rivers States, especially the Odual (Saka) and Kula communities. This was partly what informed the British decision to name the area 'Brass Division' at the dawn of colonial rule.

Their deltaic environment has greatly influenced their economic experiences. Before their rivers and creeks were destroyed by the petroleum industry, their economy was dominated by fishing, salt-making, local crafts/industries and trading. Indeed, it was their effective role in these activities that led to their success in building the ancient United Nembe City-State, which attracted the European adventurers and supercargoes to the area from the $15^{\text {th }}$ century AD. The European merchants' saw the Nembe businessmen as hard bargainers because of their strong rejection of unfair offers and prices by the Europeans supercargoes. The Nembe repeatedly used the expression 'Bara sin! Bara sin!' meaning 'Hands off!' 'Hands off!', apparently showing their deep comprehension of the complex business environment they were in the $15^{\text {th }}-19^{\text {th }}$ centuries, and their determination not to be cheated. It was from this expression, 'Bara sin', that the English name of the area, "Brass' was derived. Probably from "Bara sin", to "Brasin", to "Brass". Initially, the appellation, "Brass" was used more specifically for Nembe Town or City as indicated in the diaries/journals of the Lander brothers, as well as the early missionaries (Crowther, 1907:88). A little later, however, the name "Brass" became a synonym for the entire Nembeland, or the Nembeland and Akassa Kingdom combined; or even the entire Bayelsa State. More recently, the appellation is increasingly being used to call Twon-Brass in particular, and the Brass Island, generally. On the whole, the Nembe environment has seen several human activities characterizing its history, from the fishing, salt manufacturing, farming and trading activities to the era of the internal long distance trade, and then the period of the Trans-Atlantic Trade initially in slaves, and later in legitimate agro-products. The petroleum industry which has now come, not only to dominate, but has virtually eclipsed all other activities, began in 1956 at Otabagi near Oloibiri-Ogbia, close to the boundary with Nembe. Since then Nembeland has had no dull moment, nor lasting peace.

Their traditions claim that early migrants came from the dispersal centre of Obiama led by Olodi, believed to be the senior among the eponymous ancestors of the Nembe ethnic nationality. Others were Obolo and Onyo. They are credited with the establishment of Olodiama, Oboloma and Onyoma, the most important of the seven wards, which ultimately became part of the Nembe city/metropolis.

The three Nembe patriarchs ruled as priest-kings, pere, under an ecclesiastical gerontocratic system of government. The Olodiama pere ruled Olodiama, Oboloama pere ruled Oboloama and Onyoama pere ruled Onyoma. 
However, in matters of common interest, such as the celebration of the amakoromo idu-olali, (the banana festival designed to commemorate the foundation of the nation and to appreciate the gods for their benevolence), they usually gathered at Suotugu located at Olodiama. Suotugu simply means the meeting-point of heaven and earth or the 'center of creation'. The name also suggests that the spot was the 'heart of the Nembe city or nation'. It may equally be seen as the Nembe equivalent of the Garden of Eden. It would appear that in reverence to their senior, matters bordering on ultimate judicial pronouncements at the highest level were also done at a section of Olodiama known as Ibidikiri (which was the Nembe National Supreme Court). Teknikio (1978) described "Olodioamabiri" as the "first chambers of real justice". According to oral traditions (Ukelonu, 1960), this court endured until it was terminated in the nineteenth century by King Mein, whom the European explorers, especially the Lander brothers pejoratively stigmatized as 'the noted scoundrel' and 'the most absolute authority'.

Other bands of independent ljo adventurers from dispersal points in the Central Niger Delta, particularly Obiama, now extinct, also came, but preferred to establish themselves at the littoral communities of Okpoama, Odioama, Twon, as well as the Cape Formosa communities of Beletieama, Egweama and Liama, in the present Brass Local Government Area near the Atlantic Ocean.

The Okoroma ibe in Nembe Local Government Area represents a group of communities with traditions of origin relating them to Ogbia, but with very intimate historical relations with Nembe, particularly Ogbolomabiri. This explains why most Okoroma people now speak Nembe as their first language and speak their original Ogbia language, only as a second language. Most of the settlements presently listed as "Okoroma", such as the Tereke settlements and DoguEwoama were founded in the nineteenth century by Nembe merchant princes.

Similarly, the Mini in the Nembe Local Government Area represents another group of communities with traditions of origin relating them to Ogbia, especially to the defunct ancient Ebela civilization. Later in their history, they came to establish very intimate historical relations with Nembe, especially Bassambiri.

On its part, the Obioku community is seen as a community that resulted from the high-wired politics of some principal actors in Nembe metropolis. The founder, King Wari was a son of King Ogbodo the Pacifist, the last ruler of the United Nembe kingdom and the pioneer Amanyanabo of Bassambiri. Wari reigned briefly as Ogbodo III, but for political reasons, left Nembe with his loyalists, journeyed south-eastwards, and along with along with Elder Igbologi, his nephew, founded Obioku Town near the Santa Barbara River, in about A.D 1773 (Obioku Internal Affairs Society 1989:1-3; Memo to the Revenue Mobilisation Allocation and Fiscal Commission, 31/1/2005:4).

Again, most of the communities in the lkensi-ibe were founded in the eighteenth and nineteenth century by Nembe merchant princes, especially from Bassambiri. The area was once under some Mini influence in earlier times. Their principal communities include Ikensi Town which also is their headquarters and one of the oldest in the area. The others are Agada, Atubo, Elemuama, Obiata, Iseleogono, Biokponga, Egenelugu and Enyumama. From these communities some enterprising men and women have moved out to establish scores of other settlements. The Igbeta Ewoama group is in some ways akin to the Ikensi group. It is to the Ogbolomabiri community what the lkensi group is to the Bassambiri community. The Igbeta Ewoama ibe is the first elbow room of the Nembe in their westward expansion.

Of course, it is common knowledge that the entire Oluasiri-ibe was acquired legally and diplomatically from their north-eastern neighbours and allies, the Odual (Saka) people of the Abua/Odual Local Government Area of Rivers State at the dawn of the second decade of the $20^{\text {th }}$ century AD principally by Bassambiri leaders and adventurers (Akere, 1993).

The Nembe nation therefore grew by natural processes and through the incorporation of migrant populations from divergent backgrounds such as the ljo, Itsekiri, Mini and Okoroma. Each of these groups has introduced some new political, religious, cultural, social and economic innovations that have not only survived to the present, but have equally enriched the Nembe heritage. The ljo group, for instance, was responsible for laying the foundation of the primeval Nembe community through the establishment of some of the earliest collective institutions of the Nembe man, such as the Suotugu (the Centre of Creation or the Nembe equivalent of the Garden of Eden); and the Ibidikiri Supreme Court and judicial traditions. One of the core traditional symbols of the Nembe, the periwinkle, a small edible mollusc is believed to be associated with ljo group. The Itsekiri (misconstrued as Bini by the traditionalists) are also remembered for introducing Ogidiga, which has grown from being a war-god to become the Nembe national deity. Its temples are at Oruamabiri and Sikaka-polo in the Bassambiri quarters of the city. Eventually this deity came to provide some means of unifying all the component communities of the Nembe city-state through religious ties and sanctions. Virtually all the principal deities of the other Nembe subgroups accept Ogidiga as either their 'father' or 'husband', or at least as a 'senior brother'. This preeminent position is aptly captured in the one of the praise names of Ogidiga, namely, Senengimo-pere, meaning 'the all-conquering priest-king'. Okpoama community is also proud of its unique place in the Nembe heritage (Alagoa, 1971:12-13), not only for her reputation of being a leading fishing community, a reason for which the English traders 
called it "Fish-Town"; but particularly for her reputation for toughness and bravery. Her fighting spirit is recognised by all Nembe people. Okpoama was therefore the custodian of the ado or 'war powder' in the Nembe nation, and consequently, had the privilege of firing the first shot whenever the Nembe City State went to war (Alagoa, 1971:12-13). The Cape Formosa communities, especially Beletiema, Egwema and Liama, as well as the Odioama made their marks as excellent canoe-carvers, an activity that was sine qua non for the survival man in the Niger Delta swamp region. There are clear commonalities between the Okoroma and Mini cultural influences in Nembe. Historical linguists suggest that both are speakers of a Central Delta variety of the Niger-Congo language family, and appear to have entered the Niger Delta from the east about 2,000 years ago. Both also share a lot with the neighbouring Ogbia people, even if many of them now claim a Nembe identity. It is no mere coincidence therefore, that their traditional symbols are identical. In the early years of modern local government administration, both groups identified themselves with logos bearing the oil-palm tree. It is known that universally, the oil-palm tree symbolizes all-round prosperity. Historical linguists (Ozo-mekuri, et al,2009; Williamson, 2009) have also suggested that the Okoroma and Mini played a key role in the introduction of some East Asian food plants like cocoyam, plantain, banana, water-yam to the Central Niger Delta. Specifically, the Mini (who call themselves Abureni) have through the efforts of such great leaders as Kala-Ekule, Ogio and Peresuo contributed perhaps more than most other groups to enrich the Nembe heritage. Alagoa (1972 and 2005:126) introduced him as "a descendant" or "son" of Olodi, the founder of Olodiama. The Nembe oral traditions see him as the greatest leaders they have ever produced. His greatness is hinged on the fact that unlike his predecessors who were contented with presiding over small and less significant socio-political formations as pere, that is, priest kings, he decided to create a monarchical system in which the leaders came to concentrate mainly on their political and administrative roles, leaving the priestly functions to religious and ritual specialists. It was under such conditions that he brought together the erstwhile autonomous and semi-autonomous communities of Olodiama, Oboloma and Onyoma, as well as several other less known settlements in and around Nembe metropolis, to form the one United Kingdom of Nembe. It is on account of this great role that his name has come to be engrained on many national monuments and institutions, including the Nembe amatemesuo kule, national anthem:

Kala Ekule ama Nembe, Kala Ekule ama Nembe, Ama doko doko biokpo; meaning Kala Ekule's city, Nembe, Kala Ekule's city, Nembe, The small brave city-state King Ogio, also of Mini extraction brought some peculiar mortuary rites, furo-digi, a post-mortem examination of corpses to establish the presence or absence of the taint of witchcraft or sorcery in a matrilineage. Again, King Peresuo also from Mini is best remembered for being the father of Kings Obia and Basuo, and by implication, the grand-ancestor of the two (or three) ruling dynasties in the modern Nembe kingdoms of Bassambiri and Ogbolomabiri. Both the Ogbodo and Mein dynasties of Bassambiri and the Mingi dynasty of Ogbolomabiri were founded and occupied by descendants of King Peresuo. Alagoa (1976:345) also suggests that the beginnings of the House system in Nembeland may have appeared during the reign of Peresuo, since the House that bears that name is the oldest remembered House, today. We notice also that most of the Nembe leaders that were derived from the Abureni area, such as King Peresuo, as well as Chiefs Derri and Omoni of the King Pegi Group of Houses in Bassambiri, all have the spider, eteme-teme, heraldic symbol, conspicuously displayed on their flags and mausoleums. The spider is a major deity worshipped in the Ancient Ebela (or Ebala?) kingdom and civilization. It is a totem depicting mystery, subtle power, and virtual invincibility (Alagoa 2000:35).

Beside the individual and collective contributions already highlighted, the Nembe as a people are also celebrated for other miscellaneous roles in the advancement human culture and civilization. The current pattern of dressing known as the ljo or Niger Delta traditional attire was introduced into the Bayelsa area by the Nembe, particularly those from the Ogbolomabiri and Bassambiri communities. Again, the fact that until the creation of the old Rivers State in 1967, the Nembe-ljo dialect was both the commercial, evangelical and educational lingua-franca of the Central Niger Delta is largely to the credit of the metropolitan Nembe people, especially those who served as pastors, translators, composers and evangelists. This was particularly true of the late $19^{\text {th }}$ and early $20^{\text {th }}$ centuries, when following the introduction of Christianity and western education, some Nembe sons and daughters came to play a leading role in the spread of the gospel and western education to other parts of the Niger Delta, such as Ogbia, Izon, Abua, Odual, Engenni, Ikwerre and Southern Igbo communities. In some of these places, the Nembe-ljo dialect became the second most important language after English.

From the time of Kala Ekule, a single line of kings ruled the metropolis until about the $17^{\text {th }}$ century, when as a consequence of a succession dispute, the royal family, the kingdom, as well as the capital city territory, all witnessed binary fission. Among the rulers of the United Nembe Kingdom before the split were Kings Kala-Ekule (about 14501500AD), Ogbodo, Nembe, Owagi, Ogio (around 1639), Peresuo (around 1660), Obia, Basuo (around 1700 AD) and Ogbodo, 'The Peace Maker' (c.1745 AD). While King Ogbodo, the last Amanyanabo of the United Nembe Kingdom crossed over to the Bassambiri moiety of the city (the successor community to the ancient Olodiama and Onyoma 
communities) and established his rule over the eastern half of the kingdom, his cousin, Mingi, was placed in charge of the western half with his headquarters at Ogbolomabiri (the successor community to Oboloma). This marked the dawn of the dual monarchical system in Nembe political history.

In the course of history, each of the twin kingdoms has produced great leaders, who had served not only their comparatively smaller domains and kingdoms, but also the general interest of the Nembe nationality in the spirit of brotherhood and good neighborliness. Meanwhile, the Mingi dynasty at Ogbolomabiri has produced twelve leaders, namely Kings lkata (c.1770-1780), Gboro (c.1788AD), Kulo (c.1800-1832), Amain (c.1830-1846), Kien (1841863),Constantine Ockiya (1863-1879), Koko (c.1889- Feb.1898),Rev. A.O. Ockiya (Jan.1926-1936), Francis O. J Allagoa (1954-1967), Ambrose E. Allagoa Justice Ambrose E. Allagoa (1976-2003) and Dr. Edmund M. Daukoru (since 2007). Similarly, at Bassambiri, fourteen leaders have emerged from the Ogbodo and Mein royal families that reign over them. They include Kings Ogbodo, Gbolowei, Warri, Dede, Tamuno, Kariyai and C.F Eremienyo for the main Ogbodo dynasty; and Kings Mein (in the 1830s), Duguruyai, Arisimo (died 20 July 1870), Ebifa (c.1870-Nov. 1894), Albert Oguara (24 $4^{\text {th }}$ June 1924-21st Jan.1927), Ben Warri (4th Dec 1928-1965),C.F.Amaegbe-Eremienyo(1978-1993) and Ralph Iwowari (since1995) for the Mein dynasty which for a long period dominated the political space of Eastern Nembeland. In spite of the split, however, the Nembe are known in the course of their history to have acted in unity, especially when their collective interest or destiny was threatened.

Arising from their strategic middleman role during the trans-Atlantic trade in slaves and oil-palm produce, the Nembe, especially the merchants of Bassambiri, Ogbolomabiri, Okpoama and Twon accumulated wealth, power and influence over their neighbours, such as the Ogbia, Izon, Abua, Odual, Engenni and some Igbo communities. The challenges of the Atlantic trade also brought Nembe into commercial, diplomatic, cultural and sometimes, conflictual relations with her Eastern ljo neighbours like the Bille, Kalabari, Ibani (Bonny/Opobo), and Okrika. With these sister polities the Nembe competed for trading areas along the Orashi, Engenni and up the River Niger to Aboh, Onitsha and Idah in the Middle Belt of Northern Nigeria.

By 1856, Kings Kien and Arisimo of Nembe formally signed a treaty with the British to regulate trade and comey (protection money and custom duty) on the Brass River. This treaty marked a definite turning point in the economic history of Nembe Se. They became more involved in the legitimate commerce in agricultural produce. An interesting point about the Nembe involvement in the Atlantic Trade was that they consistently resisted being marginalized or cheated by any of her trading associates. In the middlemen role between the hinterland producers and the European buyers at the coast, therefore, Nembe seems to have made a considerable degree of fortune. While the Nembe paid a little less than fair prices to the hinterland producers, she also ensured that the Europeans did not impose unfair prices on her (Busdo, 1880).

Apart from being astute businessmen, the Nembe, particularly the members of the political class were also noted and respected for their sense of nationalism, independence and dynamism. We observe therefore, that rather than being dictated to by the Europeans, the Nembe rulers worked hard to retain their control over the economic and political independence of their land, people and resources. They were known to have extended this control to even the European traders in their domain. The over-riding influence of the Nembe rulers was shortlived. From the 1880s, the British instituted a slow but steady imperialist policy with the ultimate goal of compromising the Nembe identity as an independent polity. The British eventually brought the Nembe nation down in 1895 during the Anglo-Brass war, popularly known as the 'Akassa Raid'. Nembe lost her independence and has never fully recovered. They have passed from one form of foreign domination to another through British colonialism (June $5^{\text {th }}$, 1895-October 1st, 1960) to internal colonization by the Nigerian state dominated by the ethnic majors since October 1, 1960.

As we noted earlier, the Nembe nation grew by natural processes and through the incorporation of migrant populations from divergent backgrounds such as the ljo, Itsekiri, Mini and the Okoroma, with each group introducing some new political, religious, cultural, social and economic innovations that have not only endured to the present, but have equally enriched the Nembe cultural heritage. Central to this heritage are their age-long ideological foundation and belief that 'Gbori bara-sungbali ine tibigho iku singha: A finger cannot remove a louse from the head'.(Nembe proverb); their fundamental law that whosoever caused "intrigue between the two sections of the (Nembe) town - Ogbolomabiri and Bassambiri - by false reports" be sentenced to "death" (Captain Wauton's Report/Note on Nembe); the statutory expeditions to Aboh for the procurement of the sacred yam for Ogidiga festival which according to tradition, and as confirmed by Captain Wauton, a colonial administrator, was the responsibility of "the two kings of Ogbolomabiri and Bassambiri (who) went in turns on the expedition to Aboh for the sacred yam for Ogidiga". Other ingredients of the Nembe national heritage are the statutory construction of the shrine of Onyoma pere a personality with pan-Nembe significance by the twin settlements of Nembe (Ogbolomabiri and Bassambiri) at Bassambiri as a common venture (in turns) in spite of their quarrels and rivalries (Otiotio, 1982); the Nembe/Kalabari War of the $19^{\text {th }}$ Century which though was 
triggered by a Bassambiri man, all Nembe communities were involved, purely on the basis of their fraternal solidarity and understanding; King Ebifa's altruism which made him to think so much in terms of unity (between Bassambiri and Ogbolomabiri) that when an attempt was made to set up a Roman Catholic Mission at Bassambiri, after the Anglican Church was already in Ogbolomabiri, he rejected the idea with the argument that one church was enough for Nembe (Alagoa, 1999); the Anglo-Brass War of 1895 which saw King Koko of Ogbolomabiri mobilizing the Bassambiri, Okpoama and Twon leaders strenuously and diplomatically to forge a united contingent to fight the British-chartered Royal Niger Company at Akassa; the high level of patriotism and solidarity the Nembe leaders gingered among their people, to the extent that none was willing to betray either King Koko or the common interest of the Nembe nation, even after the obvious fall of the Nembe City-State; and lastly, the manner the entire Nembe nation turned to Chief Christopher Iwowari, the de facto regent of Nembe (Alagoa, 1995), to move the area forward after the Nembe fall, especially at the Kirk Commission. This enabled him to successfully earn a legal-cum-moral victory over the Royal Niger Company (Banigo, 2009).

Now, to the more fundamental question of how and why the Nembe were able to record all these ground-breaking efforts at unity and inter-group harmony. The following principles have been isolated as the reasons for their success, particularly the Anglo-Brass War of 1895. First, there was the respect for the autonomy and individuality of each microor sub- nationality, thereby motivating each to contribute its maximum without feeling humiliated or being side-lined. Second, there was the principle of fairness by which each community was accorded what was its due in equity, especially between Ogbolomabiri and Bassambiri, to which the war booties were allocated strictly on a basis of equality. Third, as in the case of Okpoama, King Koko showed his colleague, King Obu, appreciation devoid of any suggestion of super or sub-ordination. King Koko had to demonstrate a spirit of amity and comradeship, not superciliousness. Fourth, there was also the principle of sacrifice and commitment in the common cause whereby the leaders were willing to sacrifice their time, comfort, self-dignity and narrow sectional interests for the Nembe national good. Indeed, they were all willing to stoop to conquer. In the war against negative cultural practices like twin-killing, while it is true that Chief Christopher Iwowari of Bassambiri would always be accorded a greater credit for his role, he did not constitute a one-man squad against this universally condemned custom. It is apparent that he enjoyed the active and moral support of other radical Christians and community leaders like Chief Nathaniel Yekorogha of Ogbolomabiri. In the struggle for the acquisition and retention of Oluasiri and the eastern borderlands of the Nembe nation, history indicates that there existed a very high degree of cooperation and unity of purpose among several influential groups across Nembeland. Prominent among these were the Nembe Divisional Council of Chiefs, the Brass Local Government Council, the Nembe Bibi Okolo, the Greater Nembe Development Association, the Oluasiri Development Union, and the Nembe-lbe Patriots, among others. Consequently, the Nembe nation was able to convince the various administrative and judicial panels set up by government to resolve the disputes, that, indeed, they have a good claim over the area (Akere, 1992). Apart from foregoing, a number pan-Nembe social and community development associations have been rising and falling in Nembeland, including the Nembe National Union (NNU), the Nembe Federated Union (NFU), the Nembe N'Ongu Kobriaye Choba, the Nembe National Committee founded in November, 1975, the Nembe Cultural Association, the Nembe Action Group, the Nembe Senocratic Society, the Eagle Club of Nembe (March 1988), and the Let the Light Shine Evangelical Team, among others. Lately, we have also been witnessing the renewed efforts of the Nembe-lbe Road Projects Group (NIRPG) and its successor, the Nembe Se Congress (NSC) in employing the united approach in the development of the Nembe nation, efforts that have brought about the most visible results, especially in the area of road network development (Alagoa and Okorobia, 2011).

In spite of the foregoing developments, the challenges and manifestations of ethno-nationalism and identity conflict in Nembeland have been ubiquitous and very virulent. In the main, ethno-nationalism and identity conlicts in Nembe are closely associated with the role different communities played before and during the Atlantic trade, their respective positions under the British colonial administrative system, and more recent developments in the polity.

To begin with it should be no surprise that the nature of the challenges and manifestations of ethno-nationalism and identity conflicts in Nembeland are closely related to the history of the evolution of the city-state. The point has been made that the Nembe nation grew both by natural processes and through the incorporation of migrant populations from divergent backgrounds such as the ljo, Itsekiri, Mini and the Okoroma, with each group introducing some new political, religious, cultural, social and economic innovations that have enriched the Nembe cultural heritage. To sustain this heritage, the leaders of the Nembe nation were steadfast in ensuring that the centre-periphery ties were strong. Religious and cultural institutions, including convenants, were created to cement the relationship. The economic ties were also kept alive. This remained the situation throughout the pre-Atlantic trade era. This relationship was bound to change with advent of the Atlantic slave trade, and even more during the legitimate commerce in oil-palm produce, British colonialism and beyond. 
In the centuries during which the Atlantic slave trade lasted, the Nembe were major players. They traded in slaves with the Europeans in exchange for manufactured goods, such as arms and ammunition, alcoholic drinks like gin and schnapps; salt, enamel ware, cloths, etc. The slaves traded to the Europeans were obtained mainly from the hinterland although some were also from within as ethno-linguistic evidence in the Americas has shown (Okorobia, 1999). Generally, the Nembe did not organize large-scale slave raids into the hinterland, though there were instances when they used the arms and ammunition supplied by the Europeans to intimidate and seize individuals from the hinterland. Once the slave trade was seen as 'profitable', the hinterland people engaged in different means to raise the slaves for sale to the Europeans. In Nembeland, the overseas slave trade was eventually abolished in the 1850s and replaced with oilpalm produce trade. The oil-palm trade was organized on a trust system whereby European traders gave goods to the Nembe merchants in return for agreed quantities of oil-palm produce. The Nembe traders in turn gave some of these goods to their hinterland customers, also for agreed quantities of oil-palm produce. Occasionally, the hinterland producers failed to meet their obligations in full to the Nembe merchants. This could provoke two reactions. One, in anger the Nembe merchants used force to seize individuals from offending families or villagers who became slaves, used by them as trade hands, canoe-pullers, etc. This sometimes generated an atmosphere of social instability and mutual suspicion amongst the people. Sometimes the Nembe went beyond punishing individual offending families to visit their wrat on entire communities. The Ogbia town of Anyama was invaded by an Ogbolomabiri ruler, King Boy Amain in 1846, because the community abused the "trust" regulation. In 1870, another ruler from Ogbolomabiri, King Ockiya took a punitive expedition against Okiki, an Ogbia village on the Ekole Creek for abusing the "trust" system, and for killing "a son of Kulo" named Akpana, who had gone to collect a debt. Several other Ogbia villages, including Abu, Alagba, Otanulate, Otuabhom, Emobho and Evo were attacked and destroyed by the heavily armed merchants who has entrusted goods to some unfaithful agents there. In 1869, Okpoama launched a similar attack on Otuaganagu while in 1873; Bassambiri invaded Otuedu for taking "double trust" from other middleman (Ebiwari, 1988). Bassambiri also raided the Abureni villages of Idema, Okroroba and Agrisaba, as well as some Odual (Saka) communities, for similar offences during the Atlantic trade. Two, some hinterland producers may give members of their families as pawns to the delta traders, pending when they would produce the balance. These pawns were not technically slaves. They became slave if the debt was not paid at an agreed date. Many Nembe families and chieftaincy houses have therefore come to absorb some new members through this involuntary and servile means.

The trade in palm produce required a fairly large labour force at the coast-hands for the trade with European; hands to man the trade canoes and the war canoes that convoyed the trade canoes; hands left in the hinterland to collect small quantities of oil from peasant producers for eventual shipment to the coast. Most of these hands were of servile background. Thus in the 19th century, the number of slaves in the Nembeland, actually resident there and belonging to different families or houses (wari) increased. The increase was not only due to new acquisitions but also due in part to the natural process of increase through slave breeding. The role which the Nembe traders played both in the days of the slave trade and the days of the oil-palm produce trade affected relations between them and their periphery, both within the state and hinterland delta peoples. Nembe merchants such as Chiefs Joseph Alagoa, Basuo, Dorgu, King Ockiya, Nathaniel Yekorogha, and Tengi from Ogbolomabiri and Jonathan Kieri Ombu from Okpoma established trading posts and plantations in Okoroma, and ultimately pulled that area which had hitherto enjoyed a lager degree of political and cultural independence and distinctiveness into the Ogbolomabiri commercial and political orbit. As a result of this, Ogbolomabiri settlements like Alagoa-Tereke, Tengi-Tereke, Ockiya-Burukiri, Ockiya-Iwokiri, Dorgu, Ewoama and Yekorogha-Sangakubu were founded. It was at this time also that a Bassambiri merchant, Chief Egbelu secured a foothold and an influential position in Akakumama, an old Okoroma village. Other prominent Bassambiri merchants did the same at the North-Eastern part of Nembeland. King Ben Warri founded Benikiri, Chief Isere established Iserekiri, Chief Otuma and his associate, Edein, settled at Otuma-ama, Fikoru at Fikorukiri. Other plantations such as Alagoakiri were also founded in the Oluasiri area, which was formally under Odual influence. From all indications, most of the villages in the Ikensi area were also established as plantations in the time of the palm produce trade. The 1895 AngloNembe war provided an even greater impetus to this trend as many more chiefs of both Ogbolomabiri and Bassambiri sought for refuge in the established Okoroma, Ogbia, and Abureni communities or founded entirely new ones to re-settle their subjects. Due primarily to the unsatisfactory manner most of these Nembe colonies were established in the areas that were once in Okoroma, Mini and Odual influence, there have continued to be frictions between Ogbolomabiri and Okoroma in the western flank of Nembeland as well as between Bassambiri and the Mini and Odual clans in the northeastern plank of Nembeland (Akere 1993). There is a general nationalist re-awakening amongst the indigenous communities in whose areas earlier influence the Nembe now stand.

Ironically, some of these Nembe colonies are, themselves also beginning to exert their own 'independence' from the Nembe metropolitan communities of Bassambiri and Ogbolomabiri.While the Ikensi clan has remained largely loyal, 
her younger sister-clan, Oluasiri has in recent times, been quite assertive of their local autonomy and right to control the oil and gas resources in that part of Bassambiri, Nembe. Similarly,while the Igbeta-Ewoama group of villages have remained generally respectful of the Ogbolomabiri authority over them, the core-Okoroma communities have been very assertive of their unique identity and 'independence.'

In the litoral communities (Okpoama, Twon-Brass, Odioama, Egwema, Liama, Beletieama and to an extent, Obioku ) the assertion of independence from the capital city, Nembe(Ogbolomabiri and Bassambiri), has never been louder and more vehement as has become, lately. Their desire is not just for local autonomy, but complete freedom from any semblance of subordination or super-ordination in their relationship with the capital city. Many of these peripheral communities have taken this radical position due to the arrogance and unbriddled greed demonstrated by the traditional and modern elites of Ogbolomabiri and Bassambiri extraction. In more recent times, an even steeper dimension is been observed in the intergroup relations in Nembeland. This borders on the superiority contest between the twin communities constituting the capital city, Nembe (Ogbolomabiri and Bassambiri). Lately, this has assumed an absurd dimension. From about the dawn of the First Republic, the twin settlements have been engulfed in a bitter, longdrawn contest for the soul of Nembeland, the name 'Nembe' or 'Nembe Town' or 'Nembe City'. At first the issue was over who was more suitable to be addressed as the paramount ruler or Amanyanabo of Nembe Kingdom. Like the Itsekiri versus Urhobo/ljo claims and counter claims in Warri, the Ogbolomabiri section of Nembe has been making consistent though controversal attempts at appropriating the general name, 'Nembe' to itself since 1959 when at the height of ethnic politics in the defunct Eastern Region, the Igbo-dominated regional government in Enugu manipulated into the 'Amanyanabo of Nembe' stool, the proNCNC, half-lgbo, half-ljo candidate, Chief Allagoa of Ogbolomabiri as the preferred contender for the disputed stool, against the claims of the pro-Action Group, full-blooded ljo candidate, Chief Ben Warri of Bassambiri. Since then, the Ogbolomabiri moity began a steady but gradual change of its identity from the initial 'Ogbolomabiri' to 'OgbolomabiriNembe', to 'Nembe (Ogbolomabiri)' to 'Nembe Town' to 'Nembe City'. While actively presenting herself as synonymous with 'Nembe City', she has equally been taking political and judicial steps to exclude the Bassambiri moity from the joint identity of 'Nembe'. The Bassambiri community has also been fighting back, by contesting the Ogbolomabiri attempts at monopolising the name 'Nembe'. Accordingly, she too has been transiting, though less aggressively, from the initial 'Bassambiri' to 'Bassambiri-Nembe', to 'Nembe (Bassambiri)' to 'Nembe Town'. And so each section of the two-in-one city has been conjuring all sorts of 'historical evidence' to 'prove' that she is 'the Nembe Town' or 'Nembe City', even though comparatively, the Bassambiri community has been more accommodating of the historical fact that the city is composed of the two sections, Ogbolomabiri and Bassambiri.

In a related commentary by Ejituwu (1989), communities and "groups who were signatory to the treaties signed with the European traders (also) seek to use such documents as a basis for claming superior chieftaincy status over those that had not". Here, the Nembe people, particularly those from Ogbolomabiri and Bassambiri, are the most culpable. Again, in their relationship with their hinterland commercial associates and neighbours, they were wont to look down upon the latter, who they see as 'slaves', or at best as less civilized beings. Occasionally, this contempt is reflected in the new names and identities they tried to impose on these hinterland communities. One area where this was most obvious was in the Ogbia clan, especially those villages along the Ekole Creek. Here, according to Ebiwari (1988:53) some were renamed after the most prominent Nembe agents, while others were associated with objects in the towns. Otakeme and Otuogidi, for instance, were renamed 'Ogidiama' and 'Okpiniama' respectively. Similarly, Otukpesi and Onebum were renamed 'Anyama' and 'Alagbafama' respectively, while Okodi became 'Okodogu'. According to Owonaro (1949:27) the Nembe traders in their failed attempt at cheating their Epeinbiri customers ended up renaming the Epeinbiri people as the "ikagi ama" people; later corrupted to Kaiama. "Ikagi ama" means the "land of tortoise" or "con-men or "a cunning town". The Abureni people recount similar experiences with the Nembe traders resulting in their being referred to as the "nimi ongu" or "wise people". The word "nimi" has, apparently, been corrupted into "Mini", the name by which that group is also known.

This phenomenon often led to tensions as both history and tradition reveal that the stock from which slaves are obtained carry with it a label of inferiority (Ikimi 2006) That is what has happened between the black and white races. Part of the blackman's burden is that he sold his fellow black man as slave to the European and so condemned both himself and the slave he sold to a stigma of inferiority from which we are still struggling to free ourselves.

As the $19^{\text {th }}$ century progressed, the traditional rivalry between the French and British spread to the Niger Delta. Each tried to eliminate the other, and to dominate the area economically and politically. The British had the upper hand when they succeeded in concluding new treaties with some key communities, including Nembe and established the chartered business-cum-administrative outfit, the Royal Niger Company (RNC), with its headquarters at Akassa. Akassa was then under strong Nembe influence. The attempts by the company to enforce a trade monopoly in the Nembe trading area led to the Ango-Nembe war of 1895, popularly called the 'Akassa Raid'. While the Nembe destroyed the company's 
base, the British counter-attack led to the fall of Nembe and the end of her middleman and domineering role. By this fall, the hitherto marginalised Ogbia, Izon, Akassa and Epie-Atissa communities began to enjoy direct business links with the British firms. While the Niger Company opened bases at Yenagoa (1911) and Amassoma (1921); John Holt opened stations at Oloibiri in 1903 and Trofani in 1927. The Niger Delta Palm-nut Cracking Company owned by one Robert Y. Sewell also opened a base at Yenagoa in 1911. This informs the remark by an Ogbia historian (Egiri, 1983:30), that 'indeed...the fall of Brass (Nembe) was a blessing to the Ogbia people'. This feeling is shared by other writers such as Furoko (1922). Before long, the class of wealthy traders who had hitherto been restricted largely to the Nembe communities became much more widespread throughout the sub-region.

Another important development of the 19th century was increase in inter-marriages between the Nembe merchants and the hinterland neighbours. These intermarriages were dictated by the needs of the palm oil trade. The merchant princes married women in the hinterland so that their in-laws could serve as part of their trading agents, who influenced their relations and friends to sell the palm produce to them. In the fierce competition between Nembe agents, such marriage alliances were of great value. Also these marriages were useful in times of tensions and misunderstandings. When we add to this the fact that some of the coastal traders took wives from among their slaves, also from the hinterland, we find that there was quite a bit of blood-mixing. While most Bassambiri merchants established such links with the Abureni communities of Okoroba, Idema and Agrisaba, as wells as with a few Ogbia and Odual (Saka) communities like Otuogidi, Opume and Abobiri, the Ogbolomabiri, according to Ebiwari (1988), preferred the Ogbia towns of Opume, Akiplelai, Amakalakala and Oloibiri. Some Twon Chiefs also established such links with the Ogbia. Thus the Abali House of Otuakeme-Ogbia is linked with the Yekorogha House of Ogbolomabiri, and the Shidi House of Twon. Again, the Alagoa House of Ogbolomabiri has links with several families in Otuabo, Otabagi and Otuoke, while the Ikobho House of Emakalakala established links with the Koko House of Ogbolomabiri.

Among the Nembe, there are very few families without blood linkages with hinterland families, be it their immediate or distant hinterland. In the many mindless killings that had accompanied the various inter-group conflicts and crises in Nembeland, especially those between Bassambiri and Ogbolomabiri, Twon and Okpoama, Dieama and Okpoama, Liama and Beletiama, etc blood relations have apparently been killing each other.

\section{Colonial Rule and Coastal Sub-Imperialism}

In the 19th century, especially between 1894 and 1900 when the British traders transformed themselves into conquerors and rulers, the coastal states were the first victims. Thereafter they pushed inland in the years 1900-1914, using the coastal peoples as carriers, messengers, interpreters and political agents. And so as the British established native councils and native courts in the hinterland, they appointed some of the coastal personnel who assisted them in their move into that hinterland as members of the courts they established. Such coastal court members became very important and influential in the new scheme of things and rapidly built up power and wealth for themselves as "black residents" (Ikimi, 2006). These coastal political agents saw themselves as part of the conquering force and so as sub-imperialists, wielding great power and influence, and oppressed the hinterland peoples even more than the British. For them it was a continuation of the pre-British era during which their geographical location by the coast conferred on them tremendous advantages over those in the hinterland, to whom they served as middlemen in the trade with Europeans. As the British moved into the hinterland, so the middlemen role of the coastal peoples was undermined. However, as sub-imperialists, they found a new role for themselves and exploited it to the fullest, thereby still maintaining, as it were, the balance of relations in favour of the coastal peoples. In the Western Delta, the most successful and influential British agent was Chief "Dore" or Chief Dogho. His era was seen as the era of Itsekiri dominance over their Urhobo, Isoko and ljo neighbours. In the Eastern Delta, an identical character to Chief Dogho was Chief Joseph Alagoa of Ogbolomabiri in Nembe. He was initialy the Native Authority of the Nembe area, highly respected by all and his authority was rarely challenged even by the traditional rulers of Ogbolomabiri and Bassambiri and, as new territory was added to the Nembe court area, his influence and that of Nembe spread to such outlying districts as Emelego and Saka (Odual). The consequence of this is that today, the Itsekiri and Nembe, particularly the Ogbolomabiri have come to develop an air of arrogance among their neighbours, a tendency to claim a greater measure of self importance than they can justify, thereby provoking ethno-nationalistic feeling from their neighbours.

\section{Analysis, Discussion and conclusions}

In line with her neo-colonial orientation, the Nigerian State has done little to correct the injustices arising from the British colonial administrative system. Like the British who saw governance essentially in terms of the maintenance of law and 
order to make Nigeria easily exploitable, so also have the post-colonial Nigerian governments been. New states and local governments are created without adequate consultations with the people with a view to ascertaining whether there was something in their history and culture that would justify grouping peoples together or vice versa. As for the siting of local government headquarters, there was no consultation at all. Even in the cases of Warri and Nembe where recent history should have put government on guard, government went ahead to make extremely indefensible decisions which have had the result of creating deep inter-group cleavages and the loss of hundreds of lives and properties. Writing on this, Ikimi (2006) has observed a trend whereby place names are manipulated to generete identity conflicts and ethnonationalistc controversies. In in Delta State for instance, a new local government, Warri Southwest Local Government was created in 1996 with Ogbe-ljo as headquarters. Later this was changed to Ogidigben. Before long an ljo-ltsekiri war was on leading to an unspeakable destruction of lives and property. Again another local government called Ughelli South with Oto-Ughienwe as headquarters, came into being when the former Ughelli Local Government was broken into two. The rest of the LGA was named Ughelli North with Ughelli as headquarters. The problem here, is why the former should carry an 'Ughelli' name at-all instead of Isoko when Ughelli clearly has nothing to do with it? The danger here is that, in the distant future, some controversal persons might come up with the argument that the towns in Ughelli South Local Government have always been subject to Ughelli, hence the name of the local government! A seemingly harmless action taken to reflect a purely administrative arrangement can, with time, acquire a completely different and unintended connotation.

Similarly, in Nembe, Bayelsa State, the creation of Nembe Local Government with headquarters in Nembe has become an indissoluble apple of discord and basis for avoidable bloodshed between the rival Ogbolomabiri and Bassambiri sections of Nembe Town.The truth is that while the original Nembe Local Government created by Gen Sani Abacha on 1st October, 1996 was actually for Bassambiri, the name 'Nembe' is the joint name for the twin communities of Ogbolomabiri and Bassambiri. The government should have known that a Nembe Local Government with headquarters in Nembe without the two communities was unsustainable. If the Local Government was for Bassambiri, Government should have used a less general name such as Nembe East with headquarters at Bassambiri or Nembe (Bassambiri). This would have prevented the loss of lives and property. This is because in Africa names have deep meanings, and so we must be conscious of the fact that in inter-group relations, careless use of names can lead to grave cleavages and conflicts. The same is true of Warri South-West Local Government. Since the controversal change of the name of the Itsekiri traditional stool from Olu of Itseikri to Olu of Warri, and the Itsekiri's consistent efforts at presenting 'Warri' as a synonym for 'Itsekiriland', that part of the Niger Delta have not known inter-ethnic harmony. If, therefore, the Federal Government had not created what they called 'Warri South-West' Local Government for an area that essentially ljo in ethnic composition, many Itsekiri and ljo now dead may well have been alive.

In the final analysis, we can only reiterate that ethno-nationalist sentiments and identity conflicts are a function of a people's history. But that history must be understood to provide the knowledge of how things have come to be what they are. It is only then that we can devise solutions to the challenges of inter-and intra-ethnic relations, which recognises that sustainable peace and development can only be achieved through justice.

Largely due to their geographical location, the coastal ljo and Itsekiri were not only among earliest to enjoy contacts with the Europeans, but were also among the earliest to be colonised by to the British. Having fallen to the British earlier, they became ready tools to the British in their colonisation of the hinterland communities in ways that conferred some advantages on the individuals and communities so used, such that new inequalities, injustices and conflicts between and within groups have been amplified in the region. For the most parts, the disadvantaged ethnic nationalities protested against the inequalities and injustices they suffered, but the remediation measures undertaken to correct perceived and apparent injustices have only generated new challenges in inter-and intra-ethnic relations.

The fact that the core Niger Delta terrain is an inclement one has provided an excuse for its non-development. A second reason is that in Nigerian politics core Niger Delta peoples have been minorities, especially since 1939 when Southern Nigeria was broken into Western and Eastern Regions dominated by the Yoruba and Igbo respectively. Historically, since the region did not form a unified and distinct political formation, each state or group sought to maximize whatever advantages it could secure vis-a-vis the others (Ikimi, 2006). In a nation where politics is a winner-takes-all affair, the ethnic minorities can only survive by picking from the "master's" table or fighting to be relevant by chosing their party affiliation in such a way that they are not altogether ignored in terms of amenities and development.

\section{References}

Agedah, B: "A History of Kolokuma" BA (History) Project (University of Port Harcourt) 1984. 
Akere, P. B. (1993). Conclusions of the Government of Rivers State on the Report of the Judicial Commission of Inquiry into the Disturbances/Conflicts between Akuku- Toru and Brass Local Government Areas of Rivers State under the Chairmanship of Hon. Justice Peter B. Akere, (Printed by the Government Printing Press), Port Harcourt.

Alagoa, E. J, (1970) "Long Distance Trade and States in the Niger Delta", Journal of African History, Vol. XI, No. 3.

Alagoa, E. J. (1999). Land and People of Bayelsa State: Central Niger Delta. (Port Harcourt, Onyoma Research Publications).

Alagoa, E. J. (1971) "The Development of Institutions in the States of the Eastern Niger Delta". Journal of African History XII, 2, [IAST].

Alagoa, E. J. (1972). A History of the Niger Delta: An Historical Interpretation of ljo Oral Tradition. Ibadan: (Ibadan University Press); Madison: University of Wisconsin Press.

Alagoa, E. J. (1975). King Boy of Brass. Heinmann Educational Books Ltd.

Alagoa, E. J. (1986). Noin Nengia, Bere Nengia: Nembe N'Akabu: More Days, More Wisdom: Nembe Proverbs. Delta Series No. 5. University of Port Harcourt Press, Port Harcourt.

Alagoa, E. J. (1995) Beke You Mi: The Nembe - British War of 1895. (Public Lecture delivered at Nembe during the centenary celebrations of the nembe-BritishWarin 1895.

Alagoa, E. J. (1995). Beke You Mi: Nembe Against the British Empire. Onyoma Research Publications, Port Harcourt.

Alagoa, E. J. (1995). People of the Fish and Eagle: A History of Okpoama in the Eastern Niger Delta. Isengi Communications Limited, Lagos and Port Harcourt.

Alagoa, E. J. (2000). Okpu: Ancestral Houses in Nembe and European Antiquities on the Brass and Nun Rivers of the Niger Delta. Onyoma Research Publications, Port Harcourt.

Alagoa, E. J. (2009). The Small Brave City-State: A History of Nembe Brass in the Niger Delta. Onyoma Research Publication, Port Harcourt.

Alagoa, E.J and Okorobia, A.M (2011) The Nembe Se Congress: A Study of the United Approach to Development in Nembe Se. Onyoma Research Publication, Port Harcourt.

Banigo, Y (2009). 'Capital, Religion and Conflicts in 19th Century Nembe-ljo: Chief Christopher Iwowari, 1834 -1897' in Journal of Intra African Studies.

Busdo, Adolphe (1880) The Niger and the Benue: Travels in Central Africa London: Bentleys and Son.

Chiefs and Elders of Okoroma Clan (1975) "A Memorandum by the Chiefs and Elders of Okoroma Clan to the Panel (Manned by Prof. Tamuno, Prof. E. J. Alagoa, Dr. Nwali and Dr. Friday Nwator) Currently Inquiring into Matters for the Classification of Chiefs and Identification of Clans in the Rivers State", pp.3-4.

Coleman, J. S. (1960) Nigeria: Background to Nationalism. Berkely \& Los Angeles: University of California Press. (STM).

Dike, K. O. (1956) Trade and Politics in the Niger Delta. Oxford University Press, London.

Ebiwari, D. D. (1988) A Political History of Ogbia. B. A. (History) Thesis, University of Port Harcourt.

Eboreime, O. J (1992). 'Group Identities and the Changing Patterns of Alliances Among the Epie-Atissa People of Nigeria, 1890 - 1991'. Darwin College, Cambridge : A Dissertation in part fulfillment of the requirements for the degree of Doctor of Philosophy University of Cambridge.

Egiri, C. E. (1983) Palm Oil Production and Marketing in the Ogbia and Nembe areas of the Rivers State from the early Nineteenth Century to the Present' B. A. (History) Thesis, University of Port Harcourt.

Ejituwu, N. C. and Kpone Tonwe S. (1989) "Atlantic Trade" in In Alagoa, E. J. and Tamuno, N. T. (eds), Land and People of Nigeria: Rivers State. (Port Harcourt: Riverside Communications).

Furoko, M. B. E (1992) "An Economic History of Trofani 1860 - 1960". B. A. (History) Thesis, University of Port Harcourt.

Ikime, Obaro (2006) History, The Historian and the Nation: The Voice of a Nigerian Historian. (Zaria: Heinemann Educational Books (Nigeria PIc)), pp. 207-229

Isichei, Elizabeth; A History of Nigeria (Longman, Essex) 1983.

Kohn, Hans (2008). 'Nationalism' Microsoft $®$ Encarta $₫$ 2009. (DVD) Redmond WA: Microsoft Corporation. Memo to the Revenue Mobilisation Allocation and Fiscal Commission, 31/1/2005:4).

Obioku Internal Affairs Society (1989). "Chieftaincy Stool in Obioku". (An unpublished manuscript).

Ockiya, Daniel Ogiriki (1988). My Autobiography. (Edited and published by Theodore Idibiye Francis).

Okorobia, A. M. (1999) A History of the Underdevelopment of the Eastern Niger Delta. PhD Dissertation, Department of History, Faculty of Humanities, University of Port Harcourt.

Okorobia, A. M. (2007). The Evolution of the Nembe Nation and the Emergence of the King Jacket Mein Dynasty. Niger Delta Heritage Centre, Port Harcourt.

Okorobia, A. M. 'The Impact Of The Atlantic Trade'. Alagoa, E.J.ed. The Land and People of Bayelsa State: Central Niger Delta. (Onyoma Research Publications, Port Harcourt).

Okorobia, A.M (2007) "The Language Factor in African-American Relations: The Case of the ljo and Their Diaspora" in Ngaage B.S. and Trinya, K, Prospect and Retrospect: The African-American Experience (Pears Publishers) Port Harcourt.

Otiotio, O. E. (1982) 'Onyoma: An Ancient Nembe Community'. B.A (History Project) University of Port Harcourt.

Owolo, James Yousuo M. N. and Vincent A. Daniel (1958). "Full History of Nembe" (an unpublished manuscript written at the eve of the Nembe chieftaincy dispute).

Ozo-mekuri, N. et al (2009) "Language: Some Historical Implications in Alagoa, E. J. et al (eds) The Izon of the Niger Delta. (Port Harcourt, Onyoma Research Publications).

Panter-Brick , K (1978) Soldiers and Oil The Political Transformation of Nigeria. Frank Cass, London. 
Sorgwe, C. M. (1990) "A History of Epie-Atissa: Oral and Ethnographic Dimenison". Unpublished PhD Thesis, University of Port Harcourt, Nigeria.

Teknikio A.I.M (1978) Great Nigerians of Nembe/Ogbia (BALGA); Mimeograph, LAITY Nembe.

Ukelonu, O. (1960). Report of the Commission of Inquiry into the Nembe Chieftaincy Dispute: Eastern Region of Nigeria Official Document No. 24 of 1960.

Wariboko, W. E. (1989) 'Social and Political Development'. In Alagoa, E. J. and Tamuno, N. T. (eds), Land and People of Nigeria: Rivers State. (Port Harcourt: Riverside Communications).

Wauton, E.B. Captain (1920) "Notes on Nembe", National Archives Enugu/9/1/20.

Williamson, Kay (1988) The Pedigree of Nations: Historical Linguistics in Nigeria. Inaugural Lectures No.5, University of Port Harcourt Press.

Williamson, Kay (2009) "A Common Language for the ljaw Ethnic Nationality?" in Alagoa, E. J. et al (eds) The Izon of the Niger Delta. (Port Harcourt, Onyoma Research Publications).

Willink, H. el. al. 1958. Report of the Commission Appointed to Enquire into the Fears of Minorities and the Means of Allaying Them. H. M. S. Office, London. 
